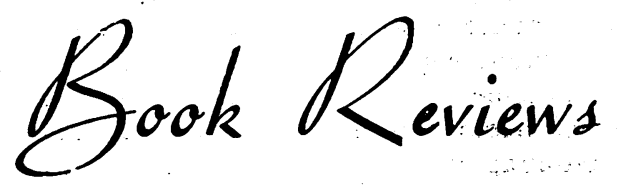

\section{A BIOCHEMICAL APPROACH TO PATHOLOGY}

By M. J. R. Dawkins and K. R. Rees. Pp. I 28. Edward Arnold Ltd., London. 1960. I 8s.

This is an excellently written little book which manages to present a large amount of information in a digestible form. The authors start with chapters on cell metabolism and subcellular organization, for which only a basic knowledge of organic chemistry is necessary on the part of the reader. They follow these up with discussions of the mechanism of action of toxic agents, of deficiency states, and of inborn errors of metabolism. There is a final chapter on biochemical changes in growth. Only 21 references in all are given, but these mostly provide general reading and further references.

The publishers state that this is a "textbook for undergraduates,' and it will certainly be of interest to this group of readers, although the term ' textbook' seems to convey a false impression. However, the book should have a much wider appeal, and there must be few people in the field of pathology, biochemistry, or, for that matter, of medicine who would fail to be interested. The material is presented from a novel point of view.

\section{RECENT ADVANCES IN SURGERY}

Edited by Selwyn TaYlor, D.M., M.Ch., F.R.C.S. Fifth edition. Pp. $500+$ xiv, with 160 illustrations. London: J. \& A. Churchill Ltd. 1959. 6os.

The new editor of this fifth edition, Selwyn Taylor, has selected a team of contributors, each of whom is an expert in his own particular field. The reader is presented with 29 excellent chapters, ranging over such subjects as heart surgery, peripheral ischaemia, the surgery of the kidney, of carcinoma of the bladder, of the parotid, of the pancreas, for portal hypertension and of the endocrine system, to mention only a few.

The editor is indeed to be congratulated on his choice of current subjects and on his presentation of them. The book is well illustrated and indexed and has an excellent up-to-date bibliography. This book will prove extremely useful to surgeons everywhere wishing to keep abreast of the recent advances in their subject and invaluable to the postgraduate studying for higher degrees.

\section{THE PHYSIOLOGY OF THE NEWBORN INFANT}

By Clement A. Smith. Third edition. Pp. 497. Blackwell Scientific Publications, Oxford. I 960. 95s.

This is the third edition of a book already recognized in the field of obstetrics, paediatrics and physiology. Much new material has been added, and many chapters re-written. With the exception of neurology, the physiology of the newborn infant is dealt with in all its aspects, and the author has written a full, but critical and readable review of the present state of knowledge in such varying fields as those of circulation and of metabolism. Each chapter ends with a useful clinical summary in which the applications to obstetrics and paediatrics are considered.

When the difficulties of investigating newborn infants are considered, the amount of information available seems remarkable. The I,355 references quoted here are some indication of the amount of work that has been done, and the author's review of these will be invaluable to obstetricians. and paediatricians, as well as of interest to physiologists and pathologists. A useful table of the known normal values in the first two weeks of life is given at the back of the book, with references to the source of the information.

\section{ANATOMY, REGIONAL AND APPLIED}

By R. J. LAST, M.B., B.Sc.(Adel.), F.R.C.S. Second edition. Pp. 741 + xvi, with 372 illustrations. London: J. \& A. Churchill Ltd. I959. 80s.

Like the first edition, this book is primarily intended for students, particularly postgraduate students, revising their anatomy for the purpose of examinations, particularly the primary examination for the Fellowship of the Royal College of Surgeons. The text is regional and is intended to be read in conjunction with prosected or museum specimens, but nevertheless it is fully and excellently illustrated.

This book, like the first edition, will prove extremely valuable to those preparing for examinations, but also as a concise and extremely clear textbook of regional anatomy it will be of inestimable value to the practising surgeon as a book to which he can refer to refresh his knowledge, in particular when called upon to explore some region which is not his everyday territory. For the academically inclined the book contains an interesting section of biographical notes and there is an excellent index. 